\title{
The effect of microplastics pollution in microalgal biomass production: A biochemical study
}

\author{
César Cunha ${ }^{a}$, Joana Lopes ${ }^{a}$, Jorge Paulo ${ }^{a}$, Marisa Fariaa,b,c, Manfred Kaufmann ${ }^{c, d}$, \\ Natacha Nogueira ${ }^{\mathrm{c}, e}$, Artur Ferreiraf, Nereida Cordeiro ${ }^{\mathrm{a}, \mathrm{c}, *}$ \\ ${ }^{a}$ LB3 - Faculty of Science and Engineering, University of Madeira, 9000-390 Funchal, Portugal \\ b Oceanic Observatory of Madeira, ARDITI, Madeira Tecnopolo, 9020-105 Funchal, Portugal \\ ${ }^{c}$ CIIMAR - Interdisciplinary Centre of Marine and Environmental Research, University of Porto, 4450-208 Matosinhos, Portugal \\ d Marine Biology Station of Funchal, Faculty of Life Sciences, University of Madeira, 9000-107 Funchal, Portugal \\ e Mariculture Center of Calheta, Fisheries Directorate, 9370-133 Calheta, Portugal \\ ${ }^{\mathrm{f}}$ CICECO - Aveiro Institute of Materials and Águeda School of Technology and Management, University of Aveiro, 3754-909 Águeda, Portugal
}

\section{A R T I C L E I N F O}

\section{Article history:}

Received 14 June 2020

Revised 3 August 2020

Accepted 31 August 2020

Available online 1 September 2020

\section{Keywords:}

Microplastics contamination

Polystyrene

Polymethyl methacrylate

Microalgae

Phaeodactylum tricornutum

Biomass

\begin{abstract}
A B S T R A C T
Microplastics (MPs) are widely spread throughout aquatic systems and water bodies. Given that water quality is one of the most important parameters in the microalgal-based industry, it is critical to assess the biochemical impact of short- and long-term exposure to MPs pollution. Here, the microalga Phaeodactylum tricornutum was exposed to water contaminated with 0.5 and $50 \mathrm{mg} \mathrm{L}^{-1}$ of polystyrene (PS) and/or polymethyl methacrylate (PMMA). Results show that the microalgal cultures exposed to lower concentrations of PS displayed a growth enhancement of up to $73 \%$ in the first stage (days 3-9) of the exponential growth phase. Surprisingly, and despite the fact that long-term exposure to MPs contamination did not impair microalgal growth, a steep decrease in biomass production (of up to 82\%) was observed. The production of photosynthetic pigments was shown to be $\mathrm{pH}$-correlated during the full growth cycle, but cell density-independent in later stages of culturing. The extracellular carbohydrates production exhibited a major decrease during long-term exposure. Still, the production of extracellular proteins was not affected by the presence of MPs. This pilot laboratory-scale study shows that the microalgal exposure to water contaminated with MPs disturbs its biochemical equilibrium in a time-dependent manner, decreasing biomass production. Thus, microalgal industry-related consequences derived from the use of MPs-contaminated water are a plausible possibility.
\end{abstract}

(c) 2020 Elsevier Ltd. All rights reserved.

\section{Introduction}

Plastics are synthetic organic polymers with wide applications in the industry, construction, medicine and food protection, due to its versatility, durability and low-cost production. In the past decades, the global production of plastics has increased significantly in order to sustain our consumerism daily lifestyle. As a result, plastic pollution has increased both in terrestrial and marine environments (Pacheco et al., 2018), raising concerns worldwide regarding the environment and human health. In 2018, the global plastic production reached roughly 400 million tonnes, of which 13 million are estimated to have been introduced in aquatic environments, mainly through indiscriminate disposal (UN, 2018). Presently, plastic debris account for $80 \%$ of

\footnotetext{
* Corresponding author.

E-mail address: ncordeiro@staff.uma.pt (N. Cordeiro).
}

the total waste in the aquatic ecosystem (Venghaus and Barjenbruch, 2017). Further, in recent years, not only large plastic pieces, but also its debris, known as microplastics (MPs), have been defined by the US National Oceanic and Atmospheric Administration (Wright et al., 2013) as small plastic particles with diameter under $5 \mathrm{~mm}$. Despite the reports of the presence of MPs in the oceans since the 1970's (More, 2008; Carpenter and Smith, 1972) and its contribution to severe oceanic pollution, only in the last decade has the issue drawn serious attention of the scientific community. This is largely due to the ubiquitous and almost indestructible nature of MPs, as well as its bioaccumulation in oceans, posing a hazard to marine biota (Cole et al., 2016). MPs are considered a widespread marine contaminant and have been found accumulated in water columns, shorelines (Browne et al., 2011) and deep-sea sediments (Van Cauwenberghe et al., 2013; Woodall et al., 2014). Further, MPs have been documented to be present in water all across the globe, from rivers (Mani et al., 2015; McCormick et al., 2016; Slootmaekers et al., 2019) to oceans 
(Avio et al., 2017; Isobe et al., 2019; Liu et al. 2019), wastewaters (Carr et al., 2016; Ziajahromi et al., 2017; Li et al., 2018) and even raw and treated drinking water (Pivokonsky et al., 2018; Mintenig et al., 2018). Two of the most commonly produced and detected MPs in aquatic environments and treated waters are polystyrene (PS) (Gambardella et al., 2018; Sun et al., 2019) and polymethyl methacrylate (PMMA; acrylic) (More, 2008; Andrady, 2011; Sun et al., 2019). PS is a low-density plastic, commonly used in the industry due to its chemical resistance and transparency, with wide applicability in packaging and technical items. Also, PMMA, a high-density plastic, is widely applied industrially and in consumer market products, due to the its high transparency level and corrosion resistance (Zeng et al., 2002).

Moreover, microalgae are the basis of the trophic chain and genuine miniature biochemical factories that are rich in valuable biological compounds such as carbohydrates, photosynthetic pigments, proteins and oil. Microalgal biomass is considered a sustainable, pollution free, ecofriendly, nontoxic and reliable promising source of renewable energy (Khan et al., 2018). Microalgalbased biofuel is arising, mostly because of its high lipid contents (Patil et al., 2008), or carbohydrates composition (20-40\% in normal conditions or up to $70 \%$ in carbohydrates productioninducing conditions), underpinning the potential of microalgae as a viable alternative for biofuel generation (Bastos, 2018). Carbohydrates have lower energy contents in comparison to other biomass compounds, such as lipids and proteins, but are still the preferable/main substrate for the production of several significant biofuels (including bioethanol, biobutanol, biohydrogen, etc.) by biotechnological conversion technologies (Markou et al., 2012). While technological, metabolic and genetic improvements have been scientifically and industrially developed in the last decade, the profitability of microalgal-based biodiesel production has still not surpassed fossil fuels (Patil et al., 2008) in order to effectively replace it. Despite the numerous efforts and research to enhance microalgal-based biofuel production, scalable and standard methods are still not feasible due to low biomass yields (Shuba et al., 2018).

Water quality is one of the most important parameters in the microalgal-based industry and its key to the success of biomass production. Wastewater treatment plants (WWTPs) are central to urban water distribution to industries and have been implicated in massive release of MPs (Sun et al., 2019). Recent studies report that, in WWTPs, over $90 \%$ of incoming plastics are isolated in the wastewater biomass and thus eliminated from the effluent stream (Carr et al., 2016; Lares et al., 2018; Talvitie et al., 2017). Still, both filtration and conventional mechanical, biological and chemical processes are unable to remove MPs $<300 \mu \mathrm{m}$ (Storck et al., 2015). Accordingly, the concentration of MPs downstream of WWTPs have been reported to be high, with a median MPs discharge value of $2 \times 10^{6}$ particles/day (Sun et al., 2019), playing a central role in contaminating industrially employed water. Further, a study by Mintenig et al. (2017) has reflected that the majority (roughly 60\%) of all MP particles in treated waters from WWTPs ranged between $50-100 \mu \mathrm{m}$, suggesting that despite filtration, the lower sized MPs might still be not removed (Verschoor et al., 2014).

To understand the industrial impact of MPs-contaminated water, it is pivotal to understand the effect of these micro-sized particles on the microalgal growth and biochemistry. Despite recent studies being published regarding the growth behaviour of microalgae under MPs exposure (Besseling et al., 2014; Zhang et al., 2017; Cunha et al., 2019a) and physiological response of phytoplankton to MPs (Sjollema et al., 2016; Long et al., 2017), the complete impact of microalgal exposure to relevant concentrations of MPs on the biomass production, photosynthetic pigments (chlorophyll-a and carotenoids), extracellular carbohydrates and proteins, as well as the correlation between these variables, has never been properly assessed. Also, no comprehensive studies have been reported on the long-term MPs exposure effects on microalgal populations, and how all these parameters have a potential huge impact on microalgal-biomass-based industries.

Phaeodactylum tricornutum is a marine diatom species, with numerous applications in biotechnology, for instance, as a biofuel precursor and recombinant protein expression host (BañuelosHernández et al., 2015). Its potential has also been reported in human and animal nutrition, health and cosmetics (Kim et al., 2012). Furthermore, $P$. tricornutum is among the most explored and studied regarding lipidic content (Fajardo et al., 2007; Yoneda et al., 2016; Lupette et al., 2019) for biodiesel production (Chisti, 2008; Branco-Vieira et al., 2017; Maeda et al., 2018; Wang et al., 2019a), specifically focused on its industrial development and application (Daboussi et al., 2014; Adler-Agnon et al., 2018; Vandamme et al., 2018). The principal aim of the current research was to determine the effect of water contaminated with low $\left(0.5 \mathrm{mg} \mathrm{L}^{-1}\right.$; environmental level) and high (50 $\mathrm{mg} \mathrm{L}^{-1}$; urban level) concentrations of PS and PMMA on the growth, biomass, photosynthetic pigments (chlorophyll- $a$ and carotenoids), extracellular carbohydrates and proteins of $P$. tricornutum. These results may provide risk references for the use of ubiquitous MPs-contaminated waters in the microalgal biochemistry and also to the microalgal biomass biotechnology industry.

\section{Materials and methods}

\subsection{Microalgae selection and culture conditions}

In the present research, the marine microalga Phaeodactylum tricornutum (Class Bacillariophyceae; 5-13 $\mu \mathrm{m}$; axenic culture) was obtained from the Spanish Algae Bank (BEA) and grown in ASP12 medium [0.714 $\mathrm{g} \mathrm{L}^{-1}$ HEPES; $28 \mathrm{~g} \mathrm{~L}^{-1} \mathrm{NaCl} ; 0.696 \mathrm{~g} \mathrm{~L}^{-1} \mathrm{KCl} ; 7$ $\mathrm{g} \mathrm{L}^{-1} \mathrm{MgSO}_{4} .7 \mathrm{H}_{2} \mathrm{O} ; 4 \mathrm{~g} \mathrm{~L}^{-1} \mathrm{MgCl}_{2} .6 \mathrm{H}_{2} \mathrm{O} ; 1.48 \mathrm{~g} \mathrm{~L}^{-1} \mathrm{CaCl}_{2} .2 \mathrm{H}_{2} \mathrm{O}$; $0.1 \mathrm{~g} \mathrm{~L}^{-1} \mathrm{NaNO}_{3} ; 0.013 \mathrm{~g} \mathrm{~L}^{-1} \mathrm{~K}_{3} \mathrm{PO}_{4} .3 \mathrm{H}_{2} \mathrm{O} ; 0.0069 \mathrm{~g} \mathrm{~L}^{-1} \mathrm{Na}_{2}$ Glycerophosphate; $0.151 \mathrm{~g} \mathrm{~L}^{-1} \mathrm{Na}_{2} \mathrm{SiO}_{3} .9 \mathrm{H}_{2} \mathrm{O} ; 0.1 \mathrm{~g} \mathrm{~L}^{-1}$ Tritiplex I; Vitamins $\left(0.0002 \mathrm{mg} \mathrm{L}^{-1}\right.$ Vitamin B12; $0.001 \mathrm{mg} \mathrm{L}^{-1}$ Biotin; 0.1 mg L ${ }^{-1}$ Thiamine-HCl; $0.0001 \mathrm{mg} \mathrm{L}^{-1}$ Niacinamide); Trace Metals (4.36 $\mathrm{g} \mathrm{L}^{-1} \mathrm{Na}_{2}$ EDTA.2 $\mathrm{H}_{2} \mathrm{O}$; $3.15 \mathrm{~g} \mathrm{~L}^{-1} \mathrm{FeCl}_{3} .6 \mathrm{H}_{2} \mathrm{O} ; 0.0019 \mathrm{~g} \mathrm{~L}^{-1}$ $\mathrm{K}_{2} \mathrm{CrO}_{4} ; 0.0119 \mathrm{~g} \mathrm{~L}^{-1} \mathrm{CoCl}_{2} \cdot 6 \mathrm{H}_{2} \mathrm{O} ; 0.0025 \mathrm{~g} \mathrm{~L}^{-1} \mathrm{CuSO}_{4} .5 \mathrm{H}_{2} \mathrm{O} ; 0.178$ $\mathrm{g} \mathrm{L}^{-1} \mathrm{MnCl}_{2} .4 \mathrm{H}_{2} \mathrm{O} ; 0.0199 \mathrm{~g} \mathrm{~L}^{-1} \mathrm{Na}_{2} \mathrm{MoO}_{4} .2 \mathrm{H}_{2} \mathrm{O} ; 0.00263 \mathrm{~g} \mathrm{~L}^{-1}$ $\mathrm{NiSO}_{4} .6 \mathrm{H}_{2} \mathrm{O} ; 0.00129 \mathrm{~g} \mathrm{~L}^{-1} \mathrm{H}_{2} \mathrm{SeO}_{3} ; 0.00184 \mathrm{~g} \mathrm{~L}^{-1} \mathrm{Na}_{3} \mathrm{VO}_{4} ; 0.023$ $\left.\left.\mathrm{g} \mathrm{L}^{-1} \mathrm{ZnSO}_{4} .7 \mathrm{H}_{2} \mathrm{O}\right)\right]$.

The initial selected cell concentration was $1.6 \times 10^{5}$ cells $\mathrm{mL}^{-1}$ to ensure that the culture could grow exponentially throughout the incubation period. The growth was monitored using a UV6300PC Double Beam Spectrophotometer at $730 \mathrm{~nm}$ for 27 days. A calibration curve $\left(\mathrm{R}^{2}=0.998\right)$ plotting cell density (cells $\mathrm{mL}^{-1}$ ) against absorbance was used to determine cell density. Microalgal cell abundance was used to determine the potential effects of water contaminated with MPs exposure. The coefficient of cell abundance variation ( $\Delta$ cell) was calculated for the MPs exposed conditions against the control (without MPs) as: $\Delta$ cell $=[(\mathrm{x}-\mathrm{y}) / \mathrm{y}] \mathrm{x} 100$, where $\mathrm{x}$ is the microalgal cell abundance in the MPs exposed conditions (cells $\mathrm{mL}^{-1}$ ) and $\mathrm{y}$ is the microalgal cell abundance in the control (cells $\mathrm{mL}^{-1}$ ). Also, the corresponding $\mathrm{pH}$ to every growth measure was performed using a benchtop $\mathrm{pH}$ meter (Hanna Instruments H12210), whose calibration was performed daily.

The experimental cultures were maintained for 27 days in a growth chamber (Aralab CP500) at $25 \pm 1^{\circ} \mathrm{C}$, under $23 \mu \mathrm{mol}$ photons $\mathrm{m}^{-2} \mathrm{~s}^{-1}$ (HOBO ${ }^{\circledR}$ Pendant ${ }^{\circledR}$ MX Temp MX2202) supplied by a cool white Osram L 18W 840 Lumilux lamp, with a 14/10 h (light/dark) photoperiod. At the end of the experimental period the biomass was recovered by centrifugation $(4427 \mathrm{~g}, 30 \mathrm{~min})$ 

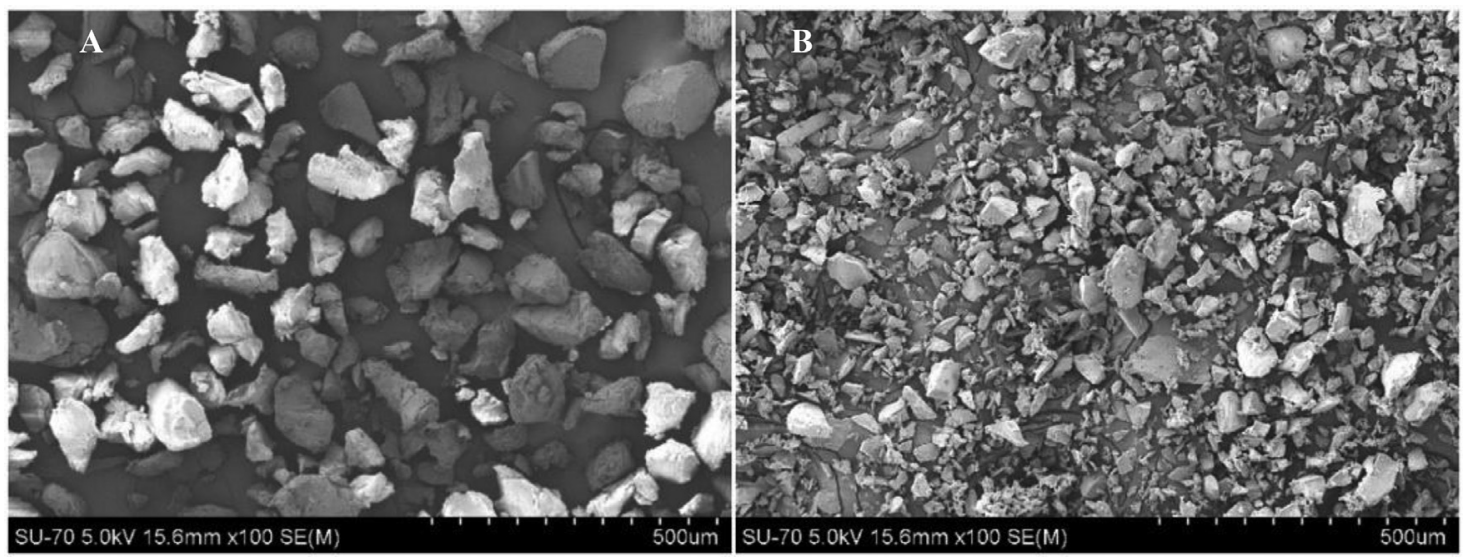

Fig. 1. Scanning electron microscopy images (x100) of the MPs: (A) polystyrene (PS); (B) polymethyl methacrylate (PMMA).

Table 1

Zeta potential $(\mathrm{mV} \pm \mathrm{SD})$ of polystyrene (PS) and polymethyl methacrylate (PMMA) microplastics used.

\begin{tabular}{lll}
\hline & \multicolumn{2}{l}{ Microplastic } \\
\cline { 2 - 3 } & PS & PMMA \\
\hline Zeta potential & $-33.11 \pm 3.50$ & $-0.457 \pm 4.93$ \\
\hline
\end{tabular}

(HERLME Z360 Centrifuge) and gravimetrically determined after freeze-drying (Savant RVT400).

\subsection{Microplastics (MPs)}

Two types of commercial plastics (UV-Granulate, Magic Pyramid Bruecher\& Partner KG, Frechen, Germany) were used: polystyrene (PS) and polymethyl methacrylate (PMMA). PS is a low-density plastic, whereas PMMA is a high-density plastic. The virgin plastics were fragmentated using a milling machine $(230 \mathrm{~V}, 50 \mathrm{~Hz}, 120 \mathrm{~W})$ and after sieved (Analysensieb-Retsch) the fraction lower than 100 $\mu \mathrm{m}$ of irregular shaped MPs was obtained (average of 70-80 $\mu \mathrm{m}$ for PS and 40-60 $\mu \mathrm{m}$ for PMMA; Fig. 1). Further, the zeta potential was evaluated to measure MPs surface charge (Table 1). Shortly, zeta potential was measured in Milli-Q water at $25^{\circ} \mathrm{C}(\mathrm{pH} 7)$ using a Zetasizer Nano ZSP (Malvern). The measurements were performed in triplicate and averaged for three consecutive analysis of the same samples, with 100 runs each.

Since MPs are known to contain several organic contaminants and that these have shown adverse effects on microalgal biochemistry (Cunha et al., 2019b), MPs were washed with $n$-hexane on a magnetic stirrer for $3 \mathrm{~h}$, at room temperature, in order to remove polymer-bound organic pollutants. After, the MPs were filtered, oven-dried at $40{ }^{\circ} \mathrm{C}$ overnight and kept in a desiccator until further use. Two distinct MPs stock solutions at two concentrations were prepared in ASP-12 medium: low concentration was 1 $\mathrm{mg} \mathrm{L}^{-1}$ and higher concentration was $100 \mathrm{mg} \mathrm{L}^{-1}$. Solutions were kept in glass flasks at $4^{\circ} \mathrm{C}$ during the experimental period. Tween $20(0.1 \%, v / v)$ was added to each solution to ensure the homogeneity.

\subsection{Scanning electron microscopy (SEM)}

SEM micrographs (Fig. 1) of the MPs surface were obtained using an HR-FESEM SU-70 Hitachi Scanning Electron Microscopy equipment, operating with a $5 \mathrm{kV}$ beam, at a $15.6 \mathrm{~mm}$ working distance, in the field emission mode. Images were collected at x100 magnification. Prior to analysis, the samples were
Table 2

Samples designation relatively to the microplastic type and contamination level used.

\begin{tabular}{llll}
\hline & \multicolumn{2}{l}{$\begin{array}{l}\text { Microplastic concentration } \\
\left(\mathrm{mg} \mathrm{L}^{-1}\right)\end{array}$} & \\
\cline { 2 - 4 } Contamination level & PS & PMMA & \\
\hline Without contamination & - & - & Control \\
Low contamination level & 0.5 & - & PS 0.5 \\
& - & 0.5 & PMMA 0.5 \\
& 0.25 & 0.25 & PS+PMMA 0.5 \\
High contamination level & 50 & - & PS 50 \\
& - & 50 & PMMA 50 \\
& 25 & 25 & PS+PMMA 50 \\
\hline
\end{tabular}

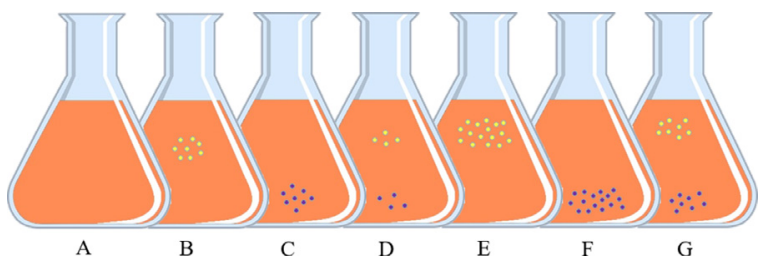

Fig. 2. Schematic of the experimental groups (exposure conditions to MPs) applied to P. tricornutum: (A) control - without contamination; (B) PS 0.5; (C) PMMA 0.5; (D) PS+PMMA 0.5; (E) PS 50; (F) PMMA 50; (G) PS+PMMA 50. Each dot colour and density represent its corresponding microplastic. Low-density MPs: yellow PS. High-density MPs: purple PMMA.

coated with a thin layer of carbon using EMITECH K950X Turbo Evaporator and deposited on a steel plate.

\subsection{Exposure conditions of microalgae to water contaminated with MPS}

Seven experimental groups (Table 2) were prepared in triplicate: one control group, using the selected microalgae grown in their correspondent medium without MPs (Fig. 2A); and six experimental groups in which the microalga was subjected to growth medium with distinct concentrations of both PS and PMMA, alone and combined: $0.5 \mathrm{mg} \mathrm{L}^{-1}$ (low concentration/environmental level; Fig. 2B-D) and $50 \mathrm{mg} \mathrm{L}^{-1}$ (higher concentration/urban level; Fig. 2E-G). Given the lack of standardization in expressing the concentration of MPs in water between field (particles/unit of $\operatorname{area}^{3}$ ) and laboratory (weight/volume) studies, it is challenging to establish relevant concentrations to the scope of each study. Still, the environmental and urban water MPs concentrations used here were calculated based on the most recent data relevant 
(Venghaus and Barjenbruch, 2017; Everaert et al., 2018; Sun et al., 2019; Guo et al., 2020). Environmental estimated particle diameter and weight were accounted for, as well as the morphology heterogeneity caused by the high share of fibres and fragments identified in field studies.

The microalgal cultures were allowed to grow for 27 days in $100 \mathrm{~mL}$ glass erlenmeyer flasks and were manually stirred 3 times a day in order to ensure full contact between MPs and the water phase. Microalgal cell abundance and the biochemical parameters were evaluated every week (days 1, (3), 6, (9), 13, (16), 20, (23) and 27).

\subsection{Photosynthetic pigments determination}

Photosynthetic pigment production was determined based on the Lichtenthaler method (Lichtenthaler, 1987), with some modifications. Briefly, $5 \mathrm{~mL}$ culture was centrifuged (12100 g, $4 \mathrm{~min}$ ), the supernatant discarded, and the pellet resuspended in $5 \mathrm{~mL}$ of $90 \%$ methanol. The sample was then sonicated for $5 \mathrm{~min}$, incubated in the dark at $4{ }^{\circ} \mathrm{C}$ for $24 \mathrm{~h}$ and centrifuged (12100 g, 2 min). The chlorophyll- $a$ (chl- $a$ ), chlorophyll- $b$ (chl- $b$ ) and total carotenoids (car- $t$ ) were determined in a UV-6300 PC Double Beam Spectrophotometer using the absorbance at $470\left(A_{470}\right), 652\left(A_{652}\right)$ and $665 \mathrm{~nm}\left(\mathrm{~A}_{665}\right)$, and corrected by subtracting the absorbance at $750 \mathrm{~nm}$ (turbidity), using the following equations:

$$
\begin{aligned}
& \operatorname{chl}-a\left(\mu \mathrm{g} \mathrm{mL}^{-1}\right)=16.82 \mathrm{~A}_{665}-9.28 \mathrm{~A}_{652} \\
& \operatorname{chl}-b\left(\mu \mathrm{g} \mathrm{mL}^{-1}\right)=36.92 \mathrm{~A}_{652}-16.54 \mathrm{~A}_{665} \\
& \operatorname{car}-t\left(\mu \mathrm{g} \mathrm{mL}^{-1}\right)=\left(1000 \mathrm{~A}_{470}-1.91 \mathrm{chl}-a-95.15 \mathrm{chl}-b\right) / 225
\end{aligned}
$$

\subsection{Extracellular carbohydrates determination}

Extracellular carbohydrates were determined using a modified phenol-sulfuric acid method, according to DuBois et al. (1956), where $0.5 \mathrm{~mL}$ of $5 \%(\mathrm{v} / \mathrm{v})$ phenol aqueous solution was added to supernatant $(1 \mathrm{~mL})$ of the centrifuged culture (12100 $\mathrm{g}, 4 \mathrm{~min})$. This was promptly followed by $2.5 \mathrm{~mL}$ of concentrated sulfuric acid and left for $10 \mathrm{~min}$ to react, vortexed and another $20 \mathrm{~min}$ in a room temperature water bath for colour development. Absorbance was measured at $490 \mathrm{~nm}$ in an UV-6300 PC Double Beam Spectrophotometer. A calibration curve was made with $D-(+)$-Glucose (99.5\%, Sigma Aldrich $\left.{ }^{\circledR}\right)$, using a freshly prepared stock solution (500 $\left.\mathrm{mg} \mathrm{L}^{-1}\right)$ diluted to $5,10,15,20,25$ and $50 \mathrm{mg} \mathrm{L}^{-1}\left(\mathrm{R}^{2}=\right.$ 0.9975).

\subsection{Extracellular protein determination}

To determine proteins in the supernatant (extracellular proteins) a modified Lowry et al. (1951) method was implemented. Cultures were centrifuged (12100 $\mathrm{g}, 4 \mathrm{~min})$ to remove microalgae and other debris. The centrifugation time and speed should be adjusted to the cell abundance of the sample to assure a cell-free supernatant. Reagent $\mathrm{A}\left(2 \% \mathrm{Na}_{2} \mathrm{CO}_{3}\right.$ in $\left.0.1 \mathrm{~N} \mathrm{NaOH}\right)$ was mixed with reagent $\mathrm{B}\left(1 \% \mathrm{C}_{6} \mathrm{H}_{5} \mathrm{Na}_{3} \mathrm{O}_{7}\right.$ in $\left.0.5 \% \mathrm{CuSO}_{4}\right)$ in a $50: 1$ ratio (reagent $\mathrm{C}$ ) and the Folin-Ciocalteu reagent was diluted in a $1: 1$ ratio. In a test tube, $2.5 \mathrm{~mL}$ of reagent $\mathrm{C}(10 \mathrm{~min})$ and $250 \mu \mathrm{L}$ of Folin-Ciocalteu were added to $500 \mu \mathrm{L}$ of sample, vortexed and left for $35 \mathrm{~min}$ to react. Absorbance was measured at $750 \mathrm{~nm}$ and a standard calibration curve was made using bovine serum albumin (BSA). A stock solution of $5 \mathrm{mg} \mathrm{mL}^{-1}$ was freshly prepared, being diluted to 10 , $20,50,100,200,500,1000$ and $2000 \mu \mathrm{gL}^{-1}\left(\mathrm{R}^{2}=0.9801\right)$.

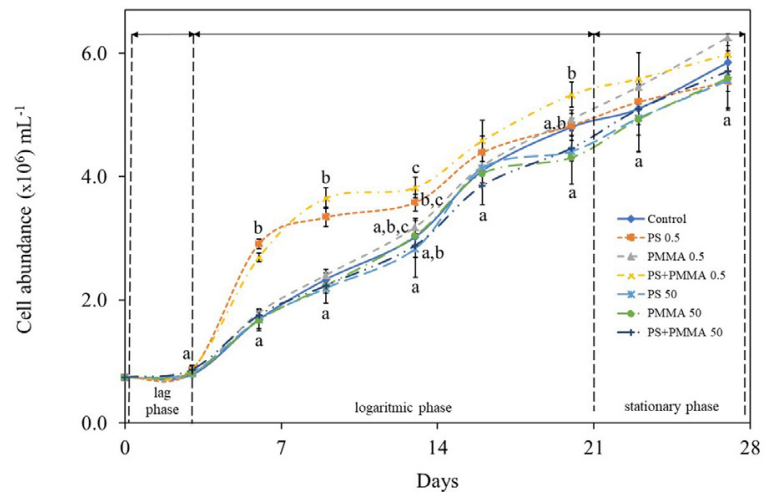

Fig. 3. Growth curves for the control (water without contamination) and for the MPs (PS and PMMA) water-contaminated conditions of P. tricornutum, throughout the 27 days experimental period. Distinct letters represent significantly different means of the correspondent time period $(p<0.05)$.

\subsection{Statistics analysis}

Statistical analysis of microalgal growth rate, biomass, $\mathrm{pH}$, photosynthetic pigments, extracellular proteins and carbohydrates production were performed using IBM SPSS statistics software (V 25). Differences in growth rate, $\mathrm{pH}$, biomass, photosynthetic pigments, extracellular carbohydrates and proteins between different experimental conditions were assessed by one-way analyses of variance (ANOVA), with a level of statistical significance of $p$-value $<0.05$. The presented results with distinct letters represent significantly different means to $p<0.05$.

\section{Results and discussion}

\subsection{Microalgal growth and biomass}

\subsubsection{Microalgal growth}

The microalgal growth for the control and polystyrene (PS) and polymethyl methacrylate (PMMA) exposed conditions are shown in Fig. 3. P. tricornutum cell abundance $\left(\times 10^{6} \mathrm{~mL}^{-1}\right)$ was determined to evaluate the possible effects of PS and PMMA microplastics (MPs) exposure. Until day 3, microalgal cultures remained in the lag phase of the growth curve (Fig. 3), without significant differences in cell abundance $(p<0.05)$ across conditions. Between days 6 and 9 , the cultures exposed to $0.5 \mathrm{mg} \mathrm{L}^{-1}$ of PS (PS 0.5) and $0.25 \mathrm{mg} \mathrm{L}^{-1}$ of PS $+0.25 \mathrm{mg} \mathrm{L}^{-1}$ of PMMA (PS+PMMA 0.5) exhibited a significant increase in cell abundance against the other MPs-exposed conditions in study. The increased cell abundance, at this stage, is likely linked to the microalgal ability to colonize MPs (Cunha et al., 2019a), which have been shown to act as substrate to enhance microalgal growth (Yokota et al. 2017; Canniff and Hoang, 2018). These results are coherent with the rise of $\mathrm{pH}$ observed, in Fig. 4, as expected.

Results from day 13 onwards show that, despite the higher cell abundance in the PS 0.5 and PS+PMMA 0.5 conditions, the growth tendency slowed down until day 21, where no significant differences were found across conditions $(p<0.05)$ (Fig. 3; Table S1). Further, between days 20 and 27, all cultures shifted to the stationary phase, which again was corroborated by the lower $\mathrm{pH}$ values (Fig. 4). The correlation between growth and $\mathrm{pH}$ is further discussed.

Interestingly, as described in Table S2, when comparing specific single vs combined PS and PMMA exposure, for both experimental concentrations, no correlation is observed for the highest concentration conditions $\left(50 \mathrm{mg} \mathrm{L}^{-1}\right)$. However, in the first-stage response (days 1-14) to $0.5 \mathrm{mg} \mathrm{L}^{-1}$ MPs exposure, the cultures exposed to PS (PS 0.5 and PS+PMMA 0.5) registered a significant 


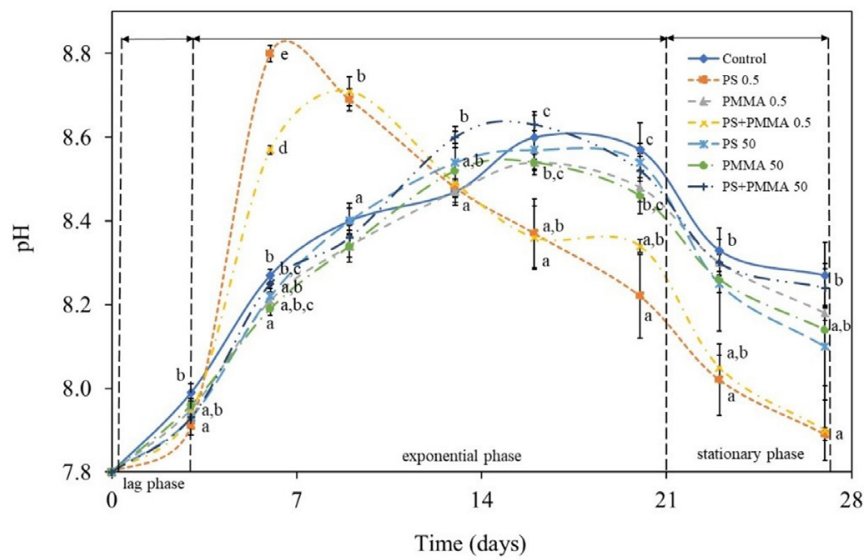

Fig. 4. pH values obtained for the control (water without contamination) and for the MPs (PS and PMMA) water-contaminated conditions of P. tricornutum, throughout the 27 days experimental period. Distinct letters represent significantly different means of the correspondent time period $(p<0.05)$.

increase in cell growth, suggesting that the growth enhancement effects are likely polymer-specific. Despite the correlation between cell growth and $\mathrm{pH}$ variation, the same effect is observed in the first-stage response, with an increase in $\mathrm{pH}$ in the cultures exposed to $0.5 \mathrm{mg} \mathrm{L}^{-1}$ of both pure and combined mixtures of PS (Table S3). On the other hand, the culture $\mathrm{pH}$ shifted to lower values compared to the PMMA 0.5 cultures, exhibiting a better correlation with biomass loss than cell growth parameters.

Lastly, from days 16 to 27 (second-stage response), there were no significant differences $(p<0.05)$ in cell abundance, across all conditions, except in day 20, where significant differences were found between the low concentration PS+PMMA 0.5 condition and the higher concentration MP-exposed PS, PMMA and PS+PMMA 50 cultures.

Recent studies (Prata et al., 2019) corroborate these observations, showing that the effects of MPs contamination are temporary, with adaptive responses following the initial period of susceptibility, leading to a noticeable recovery. Data presented in Fig. 5A further confirms this observation, showing that short exposure to MPs contamination induced an overall greater shift in cell abundance. On the other hand, Fig. 5B confirms that the influence of MPs contamination on cell abundance is time-dependent rather than concentration-dependent.

Further analysis of previously published data highlights the inconsistency of growth results (Liu et al., 2019; Sjollema et al., 2016;

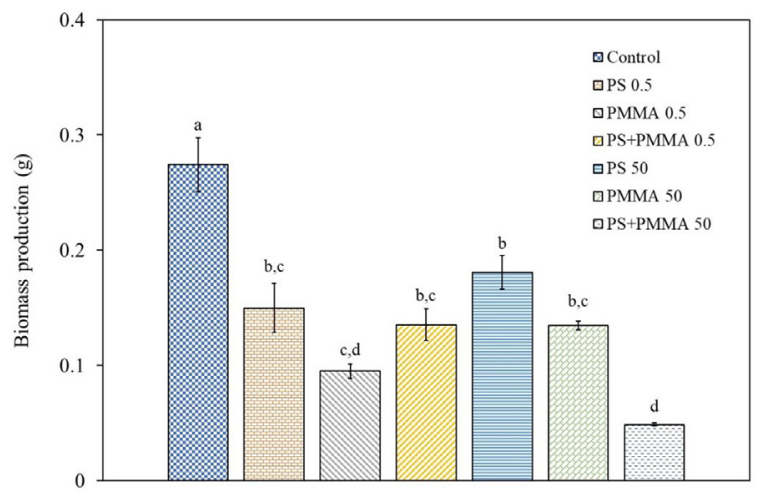

Fig. 6. Biomass production for the control (water without contamination) and for the MPs (PS and PMMA) water-contaminated conditions of P. tricornutum, throughout the 27 days experimental period. Distinct letters represent significantly different means of the correspondent time period $(p<0.05)$.

Long et al., 2017; Lagarde et al., 2016; Gambardella et al., 2019; Wang et al., 2019b). MPs have shown to induce dissimilar effects, negatively influencing the growth of Microcystis panniformis and Scenedesmus sp. (up to $42 \%$ ) while having no effect on the growth of Tetraselmis sp., in concentrations varying from 12.5 to $125 \mathrm{mg}$ $\mathrm{L}^{-1}$ (Cunha et al., 2019a). Also, Guo and colleagues (2020) have shown that besides the type of polymer (polyethylene, polypropylene, polyvinyl chloride and PMMA), one of the major factors that could affect microalgal growth is polymer size. The authors found that micrometre scale polyethylene $(150 \mu \mathrm{m})$ and unplasticized polyvinyl chloride $(250 \mu \mathrm{m})$ inhibited $P$. tricornutum cell growth and induced lipid accumulation following a nine-day exposure test. Since the polymer size was within the range of our study, differences in the results might be assigned to other factors, such as polymer concentration and test duration.

\subsubsection{Microalgal biomass}

Shockingly, at the end of the experimental period ( $27^{\text {th }}$ day), P. tricornutum cultures exposed to the different MPs-contaminated water exhibited a significant lower biomass yield $\left(\mathrm{g} \mathrm{L}^{-1}\right)$ compared to the no contaminated condition ( $p<0.05$; Fig. 6). These results allow to hypothesize that contamination with MPs could induce a shading effect, hindering the microalgal exposure to light and negatively affecting microalgal growth and photosynthetic efficiency. However, by the stage of biomass harvesting, all P. tricornutum cultures displayed statistically similar cell abundance (Fig. 3). Also, only the PS 0.5 and PS+PMMA 0.5 conditions displayed a
A

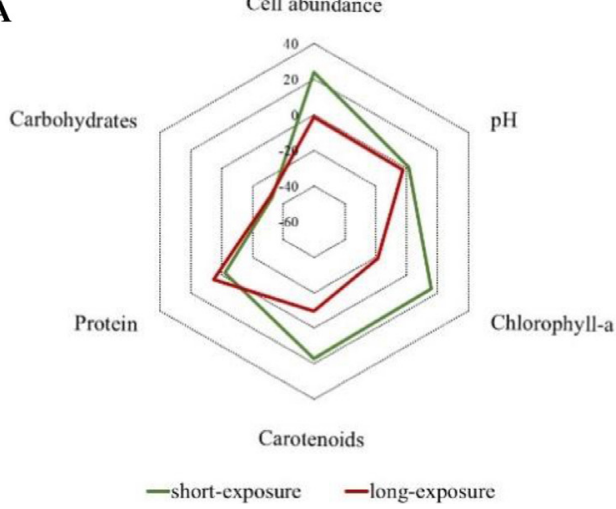

B

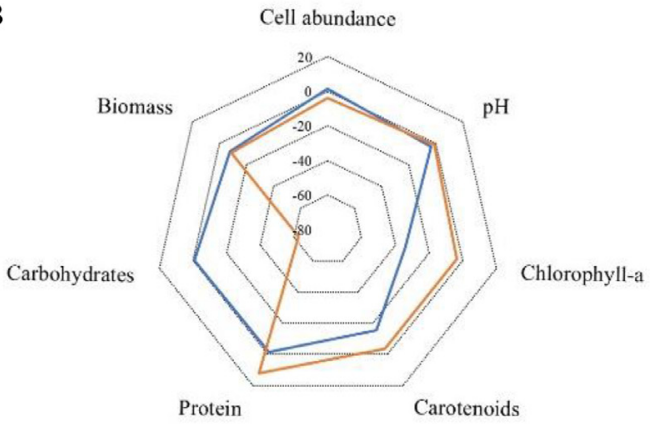

-low concentration - - high concentration

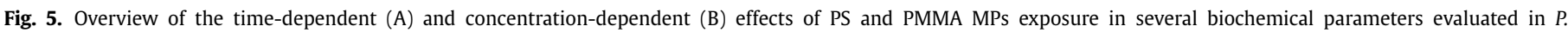

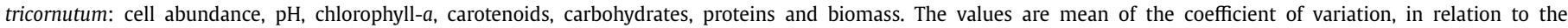

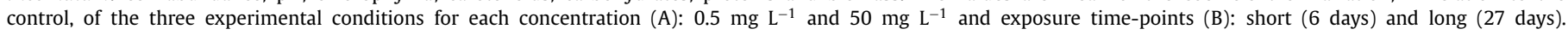
Positive/negative values represent an overall increase/decrease, respectively, in relation to the control (without contamination). 

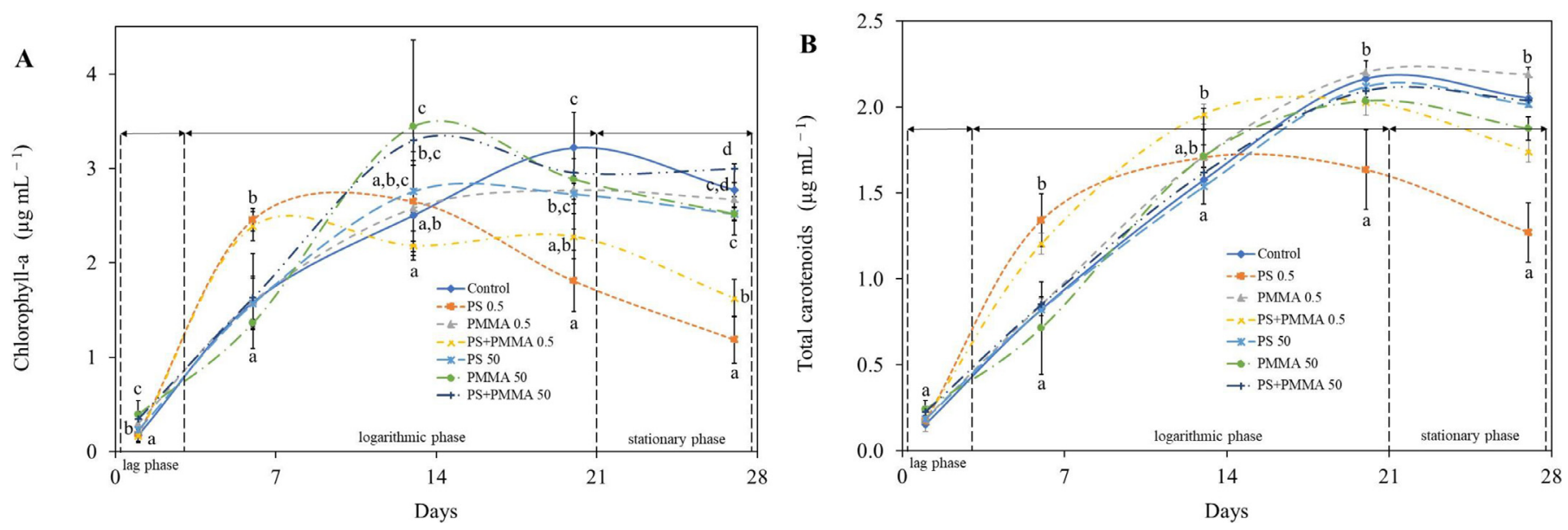

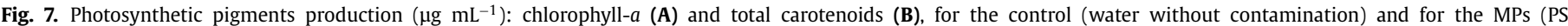

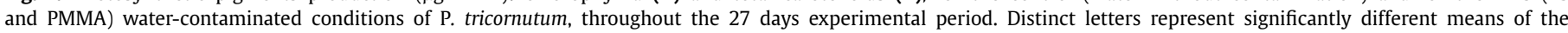
correspondent time period $(p<0.05)$.

decrease in the chl- $a$ (Fig. 7A) and car- $t$ (Fig. 7B) by the $27^{\text {th }}$ day. Fig. 6 shows that the $P$. tricornutum cultures exposed to the low concentrations $\left(0.5 \mathrm{mg} \mathrm{L}^{-1}\right)$ of MPs contamination: PS 0.5, PMMA 0.5 and PS+PMMA 0.5, exhibited a consistent decrease against the control: 45, 65 and 51\%, respectively. On the other hand, P. tricornutum exposed to the higher concentration of contaminants (50 $\mathrm{mg} \mathrm{L}^{-1}$ ): PS 50, PMMA 50, PS+PMMA 50 also showed a major decrease in biomass yield against the control: 34,51 and $82 \%$, respectively, despite the results being more variable with the MPs type. Further, when comparing single vs combined MPs exposure, for each given concentration (Table S4), for the cultures exposed to lower concentrations of MPs, no clear correlation is observed for increased biomass reduction when exposed to both types of MPs. On the other hand, higher MPs contamination exhibited a major decrease in biomass yield when exposed to the mixture of PS and PMMA, suggesting that multiple types of polymers have the enhanced potential to decrease biomass when compared to exposure to single polymer type.

Overall, the reduction in biomass yield seems to be independent of the MPs concentration (Fig. 6) and of microalgal growth/photosynthetic activity, suggesting that, at this range of contamination, the presence of MPs is enough to drive an extensive decrease in biomass yield. Hence, the results suggest that use of water contaminated with MPs influence microalgal cell size/weight, reducing biomass yield without affecting cell abundance. It has been shown that the exposure to MPs can induce morphological changes in microalgal cells, causing damage to the pyrenoids, thylakoids, plasma and cell wall (Mao et al., 2018), as well as interfering in cell division (Chae et al., 2018), leading to a possible decrease in cell size (Yokota et al., 2017). Also, it is possible that MPs exposure may have triggered a stress response towards the reorientation of cell metabolism to produce less dense molecules, or towards the release of stock-molecules to the medium. Further studies are in progress to determine the effective cause of microalgal cell mass loss.

As previously mentioned, the main obstacle to microalgalbased biodiesel production is obtaining large quantities of biomass. As water usage is one of the most important parameters in microalgal-based biofuel production, its quality is key to the success of biomass generation. Still, the economic burden that waterrelated MPs pollution might be causing on the industry has never been perceived as real, and to the best of our knowledge, the potential impact of MPs on microalgal biomass biotechnology has never been assessed. This pilot research raises the awareness and shows that the presence of type- and concentration-relevant MPs in the water has the potential to strongly interfere with biomass production, which could ultimately affect the productivity and economic viability of microalgal-based biomass exploitation.

\subsection{Photosynthetic pigment production and $\mathrm{pH}$}

Regarding photosynthetic pigments, car- $t$ are known to accumulate from $8-14 \%$ of biomass (Henríquez et al., 2016). These pigments have been shown to possess various health-related benefits, including protective effects against cardiovascular diseases, aging and age-related macular degeneration (García et al., 2018) as well as antioxidant, anti-inflammatory and anticancer activities (Patil et al., 2008; García et al., 2018). Also, chl-a, alongside its degradation products, has been shown to possess antiinflammatory activities (Heinrich et al, 2001; Subramoniam et al., 2012). In diatoms, including $P$. tricornutum, chl- $a$ and fucoxanthin are the major light harvesting pigments (Gómez-Loredo et al., 2016). In the current research, chl- $a$ and car- $t$ content was determined in function of the MPs exposure levels over the 27 days of culturing. Fig. 7 shows that the overall production of chl- $a$ (Fig. 7A) and car- $t$ (Fig. 7B) by P. tricornutum was, by day 6 , significantly higher in two of the cultures exposed to the water with lower level of MPs contamination: PS 0.5 and PS+PMMA 0.5. The same trend was observed for the cell abundance (Fig. 3) and pH (Fig. 4) in these conditions, at this stage of culturing. An overall inversion in the production of chl- $a$ and car- $t$ starting in the $8^{\text {th }}$ day of culturing, in the PS+PMMA 0.5 , and at day 13 in the PS 0.5 conditions was observed, overlapping with the steep decrease in $\mathrm{pH}$ (Fig. 4), corresponding to higher photosynthetic rates in these cultures. Our results suggest that PS is able to induce these effects in a polymer-specific but concentration-independent manner, since no differences were found for the PMMA 0.5 condition. Overall, by day 14 all the $P$. tricornutum cultures reached an equilibrium, for cell abundance (Fig. 3), pH (Fig. 4), chl-a (Fig. 7A) and car- $t$ (Fig. 7B), with the shifting point to the second-stage response to MP exposure happening around day 14 .

Specifically respecting the $\mathrm{pH}$ variation, throughout the 27 days experiment, Fig. 4 shows that, following the cell abundance (Fig. 3) and chl-a/car- $t$ increase from days 6-9 (Fig. 7), the pH significantly increased $(p<0.05)$ in the PS 0.5 and PS+PMMA 0.5 conditions. From days 9-27, the PS 0.5 and PS+PMMA 0.5 conditions exhibited a stable decrease. The other conditions (without contamination, PMMA 0.5, PS 50, PMMA 50 and PS+PMMA 50) exhibited 
a stable $\mathrm{pH}$ increase from days 1 to 16 , after entering in a subtle decrease until the end of the experiment (days 16 to 27). As reported by Zhang (2017), the $\mathrm{pH}$ values of the cultures increase with the assimilation of carbon and nitrogen sources, which relate to the growth and photosynthetic pigment production. The $\mathrm{pH}$ variation corroborates the values obtained from the photosynthetic pigment production from days 3 to 13 (Fig. 7), with the PS 0.5 and PS+PMMA 0.5 conditions exhibiting significantly higher $\mathrm{pH}$ values $(p<0.05)$ when the production of chl- $a$ and car- $t$ was also significantly higher than other conditions (Fig. 7). From days 13-27, the decrease in $\mathrm{pH}$ in these cultures compared to the control and the other MPs exposed conditions (PMMA 0.5, PS 50, PMMA 50 and PS+PMMA 50) is followed by a considerable decrease in chl- $a$ and car-t biosynthesis (Fig. 7).

Lastly, in cultures exposed to higher contamination level of PS and PMMA MPs (50 $\mathrm{mg} \mathrm{L}^{-1}$; Fig. 7A), chl- $a$ content decreased from day 13 onwards, unlike no contaminated culture, but no consistent significant differences between polymers type and size ( $p$ $<0.05$ ) were found compared to the control. Altogether, Fig. 7A shows that chl- $a$ was affected in a higher magnitude than car- $t$ in low concentration MPs exposure, while the designated higher concentrations did not affect the overall photosynthetic pigment production. These results contradict the ones reported by Prata et al. (2019) in Tetraselmis chuii, where no concentration-response relationship was established. Regarding exposure time (Fig. 5A), overall short-exposure to MPs contamination exhibited the same increasing trend in both chl- $a$ and car- $t$ production, similarly to the data reported for the cell abundance. On the other hand, long-exposure to MPs contamination induced a mirror-like ( $v s$ short-exposure) decrease in both chl- $a$ and car-t production. Still, when considering chl- $a$ production of single vs combined MPs exposure (Table S4), the same correlation is observed here compared to the $\mathrm{pH}$ variation (Fig. 4; Table S2), with PMMA playing a seemingly negligible role in microalgal exposure to a mixture of $0.5 \mathrm{mg} \mathrm{L}^{-1}$ of PS and PMMA. Conversely, no major differences were found between cultures exposed to high concentrations of single vs combined MPs exposure. Carotenoids are shown to be more affected by the presence of low concentration PS MPs, independently of combined polymer exposure (Table S5). Overall, our results define that the production of chl- $a$ and car- $t$ is more susceptible to low MPs pollution level.

In regards to the industrial importance of photosynthetic pigments, it is known that carotenoids have widespread applications in the food, cosmetic, health and biopharma industries (Gong et al., 2016), and that the simultaneous extraction of valuable biological pigments, such as carotenoids, and lipids for biofuel production, as discussed previously, has been a focus of study in order to make microalgal biomass even more economically competitive and viable (Bai et al., 2011). Consequently, the decrease in photosynthetic pigment production, in the water with lower level of MPs contamination containing PS (PS 0.5 and PS+PMMA 0.5) may also prompt industrial consequences, particularly in pigment based-microalgae industries.

\subsection{Extracellular carbohydrates production}

Carbohydrates are the major component of the extracellular polymeric substances (EPS) released by microalgae, and are mainly constituted by the major fermentable sugars, such as glucose and mannose, present in the microalgal cell that are used for bioethanol production (Harun and Danquah, 2011). The extracellular carbohydrates production was evaluated and the results (Fig. 8) show that the extracellular carbohydrates production followed the same trend of the cell density (Fig. 3) and pH (Fig. 4) (increasing) for the PS 0.5 and PS+PMMA 0.5 conditions, evidencing a coordinated and consistent biochemical response all throughout. Until

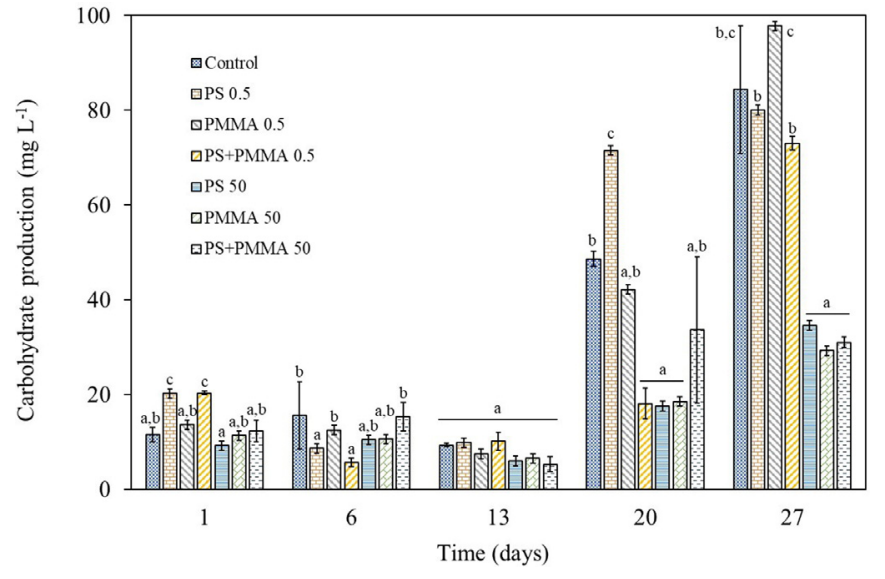

Fig. 8. Extracellular carbohydrates production for the control (water without contamination) and for the MPs (PS and PMMA) water-contaminated conditions of $P$. tricornutum, throughout the 27 days experimental period. Distinct letters represent significantly different means of the correspondent time period $(p<0.05)$.

day 13, differences found between the MPs-exposed cultures did not evidence any trend related with the presence of MPs, regardless of the concentration. Further, our results show that the extracellular carbohydrates production increased in all $P$. tricornutum cultures until the end of the experiment (Fig. 8), agreeing with the fact that microalgae produce more carbohydrates near the late exponential and stationary phases (Delattre et al., 2016). Still, at the end of the experimental period ( $27^{\text {th }}$ day), a major reduction in the carbohydrates production was exhibited in higher PS- and PMMAexposed cultures (PS 50, PMMA 50 and PS+PMMA 50) when compared to the control (Fig. 8). Hence, the effects of the MPs contamination are likely more pronounced during more advanced growth stages, from days 20-27, due to its higher EPS production near the late exponential and stationary phases. When specifically comparing the effects of single vs combined MPs exposure (Table S7), no consistent polymer- or concentration-dependent correlation was observed not for single nor combined exposure to PS and PMMA, highlighting the complexity and importance of understanding the several biochemical changes when assessing the consequences of MPs exposure. Further studies need to contemplate lipid and carbohydrate cell content to determine if higher MPs concentrations are inducing a shift in the cell metabolism and in the carbohydrate's composition.

According to Cunha et al., 2019a; 2020), most of the microalgal extracellular carbohydrates correspond to EPS and, when exposed to MPs, it is likely used by microalgae both as a defensive mechanism and as a growth enhancement mechanism, inducing homoaggregation. Further, the authors concluded that short exposure to small sized nano- and microplastics $(0.1-10 \mu \mathrm{m})$ induced the production of carbohydrates, that are used for the hetero-aggregation of nano- and micro-polymeric particles. Both PS and PMMA contaminants used in this research are considerably larger $(<100 \mu \mathrm{m})$ that the ones that induced a stimulatory effect on carbohydrates production. Thus, since microalgae are believed to use the larger sized MPs as support surface to promote growth (Cunha et al., 2019a), the production of carbohydrates is therefore decreased. Nevertheless, results found here show that the exposure to higher level of MPs contamination might have a significant impact in carbohydrates production (Fig. 7A), with possible consequences on the industrial bioethanol production. The production of bioethanol from microalgal biomass is mainly based on fermentation processes that use fermentable sugars present in both microalgal cell walls, intercellular matrices (Harun and Danquah, 2011) and extracellular carbohydrates (Goo et al., 2013). Despite the production of 


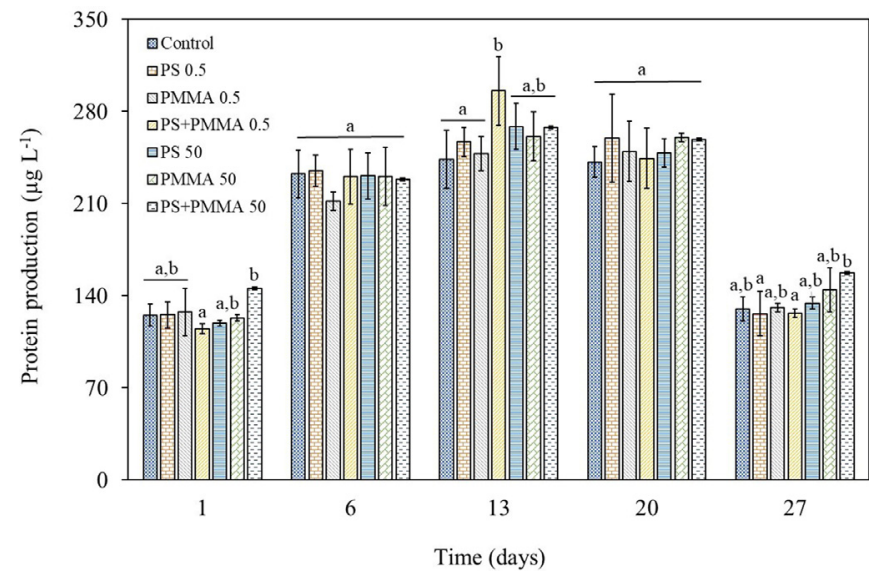

Fig. 9. Extracellular protein production for the control (water without contamination) and for the MPs (PS and PMMA) water-contaminated conditions of P. tricornutum, throughout the 27 days experimental period. Distinct letters represent significantly different means of the correspondent time period $(p<0.05)$.

third generation bioethanol derived from extra- and intracellular carbohydrates in microalgal biomass still being in developmental stages, it is expected to be the benchmark for the expansion and improvement of biofuels for years to come (Abdulla et al., 2020). Since biomass generation also plays a central role in the process of bioethanol generation, as already discussed in 3.1., even low concentrations of MPs contaminants $\left(0.5 \mathrm{mg} \mathrm{L}^{-1}\right)$, can potentially cause a severe impact on its biotechnology. Since the effects of MPs in the percentage of carbohydrates in the biomass was not evaluated here, subsequent studies should aim at understanding if MPs are affecting not only the biomass yield, but also its carbohydrates composition.

\subsection{Extracellular protein production}

The results regarding the production of extracellular proteins (Fig. 9) follow the growth curves shown in Fig. 3. From days 1-13, an increase in the production of extracellular proteins correspondent to the exponential growth phase was observed. From days 20-27, the results evidence the microalgal cultures shift to the stationary phase, as the amount of extracellular proteins produced decreased regardless of MPs exposure. Even though few significant differences were found between treatments $(p<0.05)$ along several analysis points, no clear MP type/concentration-dependent response was found for the production of extracellular proteins. Similarly to the extracellular carbohydrates production, no consistent polymer- or concentration-dependent correlation was observed when comparing the effects of single vs combined MPs exposure (Table S8).

\subsection{Call for research}

In the last decade, microalgae have been attracting ever increasing attention as a unique biomass feedstock for renewable and sustainable energy production. Its biomass can be converted to biodiesel, bioethanol and biohydrogen. Most importantly, microalgal-based biofuels represent a pollution-free and eco-friendly fuel spring that is obtained from renewable sources. Even though the investment in microalgal-based biotechnology to produce biofuels has surpassed the billion-dollar mark, its main obstacle remains obtaining large and profitable quantities of microalgal biomass. Despite recent studies having started to design strategies to enhance biomass harvesting in industrial setups (Nogueira et al., 2020), it is ever clearer that it is critical to understand all the complex operational variables of microalgal biomass generation. Given the vastly documented MPs pollution in virtually all environmental and urban aquatic pathways, it is imperative to evaluate the amplitude of the problem. Assuming nothing happens is not good enough when we are actively searching for a sustainable and economically viable energy of the future that we so badly require today. The results presented here show that, on a laboratory-scale level, the effects of MPs in regard to microalgalbiomass generation are not insignificant. Quite the opposite, in fact. These results indicate that an "invisible", but highly abundant and ubiquitous pollution in water might be playing an important role on the microalgal-biomass biotechnology industry viabilization. Therefore, detailed and highly unbiased follow-up studies in industrial setups need to be performed in order to confirm, or not, the extent of this problem.

\section{Conclusion}

This research analyses, on a laboratory-scale level, the consequences of microalgal exposure to water contaminated with MPs, to understand its biochemical effect and potential industrial consequences. A two-stage response was observed for P. tricornutum, with a polymer- and concentration-specific growth enhancement occurring in an early exponential phase, followed by an adaptive response that lead to a recovery until the stationary phase was reached. The long-term exposure to MPs did not affect the cell abundance, however a severe decrease in biomass yield was observed, even in low environmental contamination levels. While water contaminated with MPs was used, the photosynthetic pigment production, namely of chlorophyll- $a$ and carotenoids, was $\mathrm{pH}$-correlated and followed the cell density in the first stage response (lag and early exponential phases), but displayed a cell density-independent biochemical regulation in the second stage response (late exponential and stationary phases). Despite no significant differences being found for the production of extracellular proteins, the extracellular carbohydrates followed the two-stage response with focus on the negative effects of exposure to higher concentrations of MPs in later stages of culturing.

These findings address the potential effects of the use of water contaminated with MPs in microalgal-biomass biotechnology. Subsequent studies should aim to evaluate the amplitude of the effects described here in an industrial setup, to assess the potential impact of MPs-contaminated waters on the economic and commercial viability of microalgal-biomass biotechnology.

\section{Declaration of Competing Interest}

The authors declare that they have no known competing financial interests or personal relationships that could have appeared to influence the work reported in this paper.

\section{Acknowledgements}

This research was supported by the European Territorial Cooperation Programme PCT-MAC 2014-2020 through project REBECACCT (MAC/1.1.B/269) and by the Oceanic Observatory of Madeira Project (M1420-01-0145-FEDER-000001). The authors acknowledge the Spanish Bank of Algae (BEA) for making the microalga available.

\section{Supplementary materials}

Supplementary material associated with this article can be found, in the online version, at doi:10.1016/j.watres.2020.116370. 


\section{References}

Abdulla, R., King, T., Jambo, S., Faik, A., 2020. Microalgae Chlorella as a Sustainable Feedstock for Bioethanol Production. Green Eng. Campus Sustain. 81-103. doi:10.1007/978-981-13-7260-5 7.

Adler-Agnon, Z., Leu, S., Zarka, A., Boussiba, S., Khozin-Goldberg, I., 2018. Novel promoters for constitutive and inducible expression of transgenes in the diatom Phaeodactylum tricornutum under varied nitrate availability. J. Appl. Phycol. 30, 2763-2772. doi:10.1007/s10811-017-1335-8.

Andrady, A.L., 2011. Microplastics in the marine environment. Mar. Pollut. Bull. 62, 1596-1605. doi:10.1016/j.marpolbul.2011.05.030.

Avio, C., Orbi, S., Regoli, F., 2017. Plastics and microplastics in the oceans: From emerging pollutants to emerged threat. Mar. Environ. Res. 128, 2-11. doi:10. 1016/j.marenvres.2016.05.012.

Bai, M., Cheng, C., Wan, H., Lin, Y., 2011. Microalgal pigments potential as byproducts in lipid production. J. Taiwan Inst. Chem. Eng. 42, 783-786. doi:10.1016/j.jtice. 2011.02.003.

Bañuelos-Hernández, B., Beltrán-López, J., Rosales-Mendoza, S., 2015. Production of Biopharmaceuticals in Microalgae. Handb. Marine Microalgae 281-298. doi:10. 1016/b978-0-12-800776-1.00018-2.

Bastos, R., 2018. Biofuels from Microalgae: Bioethanol. Energy Microalgae Green Energ. Techn. 229-246. doi:10.1007/978-3-319-69093-3_11.

Besseling, E., Wang, B., Lurling, M., Koelmans, A.A., 2014. Nanoplastic affects growth of S. obliquus and reproduction of D. magna. Environ. Sci. Technol. 48, 1233612343. doi:10.1021/es503001d.

Branco-Vieira, M., Martin, S., Agurto, C., Santos, M., Freitas, M., Caetano, N., 2017. Analyzing Phaeodactylum tricornutum lipid profile for biodiesel production. Energy Procedia 136, 369-373. doi:10.1016/j.egypro.2017.10.251.

Browne, M.A., Crump, P., Niven, S.J., Teuten, E., Tonkin, A., Galloway, T., Thompson, R., 2011. Accumulation of microplastic on Shorelines Woldwide: Sources and Sinks. Environ. Sci. Technol. 45, 9175-9179. doi:10.1021/es201811s.

Canniff, P., Hoang, T., 2018. Microplastic ingestion by Daphnia magna and its enhancement on algal growth. Sci. Total Environ. 114, 16556-16561. doi:10.1016/j. scitotenv.2018.03.176.

Carpenter, E.J., Smith, K.L., 1972. Plastics on the Sargasso Sea surface. Science 175, 1240-1241. doi:10.1126/science.175.4027.1240.

Carr, S., Liu, J., Tesoro, A., 2016. Transport and fate of microplastic particles in wastewater treatment plants. Water Res. 91, 174-182. doi:10.1016/j.watres.2016. 01.002 .

Chae, Y., Kim, D., Kim, S., An, Y., 2018. Trophic transfer and individual impact of nano-sized polystyrene in a four-species freshwater food chain. Sci. Rep. 284, 1-11. doi:10.1038/s41598-017-18849-y.

Chisti, Y., 2008. Biodiesel from microalgae beats bioethanol. Trends Biotechnol. 26, 126-131. doi:10.1016/j.tibtech.2007.12.002.

Cole, M., Lindeque, P.K., Fileman, E., Clark, J., Lewis, C., Halsband, C., Galloway, T.S., 2016. Microplastics alter the properties and sinking rates of zooplankton faecal pellets. Environ. Sci. Technol. 50, 3239-3246. doi:10.1021/acs.est.5b05905.

Cunha, C., Faria, M., Nogueira, N., Ferreira, A., Cordeiro, N., 2019a. Marine vs freshwater microalgae exopolymers as biosolutions to microplastics pollution. Environ. Pollut. 249, 372-380. doi:10.1016/j.envpol.2019.03.046.

Cunha, C., Paulo, J., Faria, M., Kaufmann, M., Cordeiro, N., 2019b. Ecotoxicological and biochemical effects of environmental concentrations of the plastic-bond pollutant dibutyl phthalate on Scenedesmus sp. Aquat. Toxicol. 215, 105281 doi:10.1016/j.aquatox.2019.105281.

Cunha, C., Silva, L., Paulo, J., Faria, M., Nogueira, N., Cordeiro, N., 2020. Microalgalbased biopolymer for nano- and microplastics removal: a possible biosolution for wastewater treatment. Environ. Pollut. 263, 114385. doi:10.1016/j.envpol 2020.114385.

Daboussi, F., Leduc, S., Maréchal, A., Dubois, G., Guyot, V., Perez-Michaut, C., Amato, A., Falciatore, A., Juillerat, A., Beurdeley, M., Voytas, D., Cavarec, L. Duchateau, P., 2014. Genome engineering empowers the diatom Phaeodactylum tricornutum for biotechnology. Nat. Commun. 5, 3831. doi:10.1038/ncomms4831.

Delattre, C., Pierre, G., Laroche, C., Michaud, P., 2016. Production, extraction and characterization of microalgal and cyanobacterial exopolysaccharides. Biotechnol. Adv. 34, 1159-1179, doi:10.1016/j.biotechadv.2016.08.001.

DuBois, M., Gilles, K., Hamilton, J., Rebers, P., Smith, F., 1956. Colorimetric Method for Determination of Sugars and Related Substances. Am. J. Analyt. Chem. 28, 350-365. doi:10.1021/ac60111a017.

Everaert, G., Cauwenberghe, L., Rijcke, M., Koelman, s A., Mees, J., Vandegehuchte, M., Janssen, C., 2018. Risk assessment of microplastics in the ocean: Modelling approach and first conclusions. Environ. Pollut. 242, 1930-1938. doi:10.1016/j.envpol.2018.07.069.

Fajardo, A., Cerdán, L., Medina, A., Fernández, F., Moreno, P., Grima, E., 2007. Lipid extraction from the microalga Phaeodactylum tricornutum. Eur. J. Lipid Sci. Tech. 109, 120-126. doi:10.1002/ejlt.200600216.

Gambardella, C., Morgana, S., Bramini, M., Rotini, A., Manfra, L., Migliore, L., Piazza, V., Garaventa, F., Faimali, M., 2018. Ecotoxicological effects of polystyrene microbeads in a battery of marine organisms belonging to different trophic levels. Mar. Environ. Res. 141, 313-321. doi:10.1016/j.marenvres.2018.09.023.

Gambardella, C., Piazza, V., Albentosa, M., Bebianno, M., Cardoso, C., Faimali, M., Garaventa, F., Garrido, S., González, S., Pérez, S., Sendra, M., Beiras, 2019. Microplastics do not affect standard ecotoxicological endpoints in marine unicellular organisms. Mar. Pollut. Bull. 143, 140-143. doi:10.1016/j.marpolbul.2019.04.055.

García, M., López, C., Sevilla, J., Grima, E., 2018. Preparative Recovery of Carotenoids from Microalgal Biomass. Methods Mol. Biol. 107-115. doi:10.1007| 978-1-4939-8742-96.
Gómez-Loredo, A., Benavides, J., Rito-Palomares, M., 2016. Growth kinetics and fucoxanthin production of Phaeodactylum tricornutum and Isochrysis galbana cultures at different light and agitation conditions. J. Appl. Phycol. 28, 849-860. doi:10.1007/s10811-015-0635-0.

Gong, M., Bassi, A., 2016. Carotenoids from microalgae: A review of recent developments. Mar. Pollut. Bull. 32, 867-871. doi:10.1016/S0025-326X(96)00047-1.

Goo, B., Baek, G., Choi, D., Park, Y., Synytsya, A., Bleha, R., Seong, D., Lee, C., Park, J., 2013. Characterization of a renewable extracellular polysaccharide from defatted microalgae Dunaliella tertiolecta. Bioresour. Technol. 129, 343-350. doi:10.1016 j.biortech.2012.11.077.

Guo, Y., Ma, W., Li, J., Liu, W., Qi, P., Ye, Y., Guo, B., Zhang, J., Qu, C., 2020. Effects of microplastics on growth, phenanthrene stress, and lipid accumulation in a diatom, Phaeodactylum tricornutum. Environ. Pollut. 257, 113628. doi:10.1016/j. envpol.2019.113628.

Harun, R., Danquah, M., 2011. Enzymatic hydrolysis of microalgal biomass for bioethanol production. Chem. Eng. J. 168, 1079-1084. doi:10.1016/j.cej.2011.01. 088.

Heinrich, M., Bork, P., Schimtz, M., Rimpler, H., Frei, B., Sticher, O., 2001. Pheophorbide A From Solanum Diflorum Interferes With NF-kappa B Activation. Planta Med. 67, 156-157. doi:10.1055/s-2001-11496.

Henríquez, V., Escobar, C., Galarza, J., Gimpel, J., 2016. Chapter 8: Carotenoids in Microalgae. Subcell Biochem. 79, 219-237. doi:10.1007/978-3-319-39126-7_8.

Isobe, A., Iwasaki, S., Uchida, K., Tokai, T., 2019. Abundance of non-conservative microplastics in the upper ocean from 1957 to 2066. Nat. Commun. 10, 417 doi:10.1038/s41467-019-08316-9.

Khan, M., Shin, J., Kim, J., 2018. The promising future of microalgae: current status, challenges, and optimization of a sustainable and renewable industry for biofuels, feed, and other products. Microb. Cell Fact. 17, 36. doi:10.1186 s12934-018-0879-X

Kim, S., Jung, Y., Kwon, O., Cha, K., Um, B., Chung, D., Pan, C., 2012. A potential commercial source of fucoxanthin extracted from the microalga Phaeodactylum tricornutum. Appl. Biochem. Biotechnol. 166, 1843-1855. doi:10.1007/ s12010-012-9602-2.

Lagarde, F., Olivier, O., Zanella, M., Daniel, P., Hiard, S., Caruso, A., 2016. Microplastic interactions with freshwater microalgae: Hetero-aggregation and changes in plastic density appear strongly dependent on polymer type. Environ. Pollut. 215, 331-339. doi:10.1016/j.envpol.2016.05.006.

Lares, M. Ncibi, M.C. Sillanpaa, M. Sillanpaa, M., 2018. Occurrence identification and removal of microplastic particles and fibers in conventional activated sludge process and advanced MBR technology. Water Res. 133, 236-246.

Li, X., Chen, L., Mei, Q., Dong, B., Dai, X., Ding, G., Zeng, E., 2018. Microplastics in sewage sludge from the wastewater treatment plants in China. Water Res. 142 75-85. doi:10.1016/j.watres.2018.05.034.

Lichtenthaler, H., 1987. Chlorophylls and carotenoids: Pigments of photosynthetic biomembranes. Methods Enzymol. 148 (1987), 350-382. doi:10.1016/ 0076-6879(87)48036-1.

Liu, K., Wu, T., Wang, X., Song, Z., Zong, C., Wei, N., Li, D., 2019. Consistent transport of terrestrial microplastics to the ocean through atmosphere. Environ. Sci. Technol. 53, 10612-10619. doi:10.1021/acs.est.9b03427.

Long, M., Paul-Pont, I., Hegaret, H., Moriceau, B., Lambert, C., Huvet, A., Soudant, P. 2017. Interactions between polystyrene microplastics and marine phytoplankton lead to species-specific hetero-aggregation. Environ. Pollut. 228, 454-463. doi:10.1016/j.envpol.2017.05.047.

Lowry, O., Rosebrough, N., Farr, A., Randall, R., 1951. Protein Measurement with the Folin Phenol Reagent. J. Biol. Chem. 193, 265-275.

Lupette, J., Jaussaud, A., Seddiki, K., Morabito, C., Brugière, S., Schaller, H., Kuntz, M., Putaux, J., Journeau, P., Rébeillé, F., Falconet, D., Couté, Y., Jouhet, J., Tardif, M., Salvaing, J., Maréchal, E., 2019. The architecture of lipid droplets in the diatom Phaeodactylum tricornutum. Algal. Res. 38, 101415. doi:10.1016/j.algal.2019. 101415.

Maeda, Y., Yoshino, T., Matsunaga, T., Matsumoto, T., Tanaka, T., 2018. Marine microalgae for production of biofuels and chemicals. Curr. Opin. Biotech. 50, 111120. doi:10.1016/j.copbio.2017.11.018.

Mani, T., Hauk, A., Walter, U., Burkhardt-Holm, P., 2015. Microplastics profile along the Rhine River. Sci. Rep. 5, 17988. doi:10.1038/srep17988.

Mao, Y., Ai, H., Chen, Y., Zhang, Z., Zeng, P., Kang, L., Li, W., Gu, W., He, Q., Li, H. 2018. Phytoplankton response to polystyrene microplastics: Perspective from an entire growth period. Chemosphere 208, 59-68. doi:10.1016/j.chemosphere. 2018.05.170.

Markou, G., Angelidaki, I., Georgakakis, D., 2012. Microalgal Carbohydrates: an Overview of the Factors Influencing Carbohydrates Production, and of Main Bioconversion Technologies for Production of Biofuels. Appl. Microbiol. Biotechnol. 96, 631-645. doi:10.1007/s00253-012-4398-0.

McCormick, A., Hoellein, T., London, M., Hittie, J., Scott, J., Kelly, J., 2016. Microplastic in surface waters of urban rivers: concentration, sources, and associated bacterial assemblages. Ecosphere 7, e01556. doi:10.1002/ecs2.1556.

Mintenig, S.M., Int-Veen, I., Loder, M., Primpke, S., Gerdts, G., 2017. Identification of microplastic in effluents of wastewater treatment plants using focal plane array-based micro-Fourier-transform infrared imaging. Water Res. 108, 365-372. doi:10.1016/j.watres.2016.11.015.

Mintenig, S.M., Leader, M.G.J., Primpke, S., Gerdts, G., 2018. Low numbers of microplastics detected in drinking water from ground water sources. Sci. Total Environ. 648, 631-635. doi:10.1016/j.scitotenv.2018.08.178.

Moore, C., 2008. Synthetic polymers in the marine environment: A rapidly increasing, long-term threat. Environ. Res. 108, 131-139. doi:10.1016/j.envres.2008.07. 025. 
Nogueira, N., Nascimento, F., Cunha, C., Cordeiro, N., 2020. Nannochloropsis gaditana grown outdoors in annular photobioreactors: Operation strategies. Algal. Res. 48, 101913. doi:10.1016/j.algal.2020.101913.

Pacheco, A., Martins, A., Guilhermino, L., 2018. Toxicological interactions induced by chronic exposure to gold nanoparticles and microplastics mixtures in Daphnia magna. Sci. Total Environ. 474-483. doi:10.1016/j.scitotenv.2018.02.081.

Patil, V., Tran, K., Giselrod, H., 2008. Towards Sustainable Production of Biofuels from Microalgae. Int. J. Mol. Sci. 9, 1188-1195. doi:10.3390/ijms9071188.

Pivokonsky, M., Cermakova, L., Novotna, K., Peer, P., Cajthaml, T., Janda, V., 2018. Occurrence of microplastics in raw and treated drinking water. Sci. Total Environ. 643, 1644-1651. doi:10.1016/j.scitotenv.2018.08.102.

Prata, J., Lavorante, B., Montenegro, M., Guilhermino, L., 2019. Influence of microplastics on the toxicity of the pharmaceuticals procainamide and doxycycline on the marine microalgae Tetraselmis chuii. Aquat. Toxicol. 197, 143-152. doi:10.1016/j.scitotenv.2019.02.132.

Shuba, E., Kifle, D., 2018. Microalgae to biofuels: 'Promising' alternative and renewable energy, review. Renew. Sustain. Energy Rev. 81, 743-755. doi:10.1016/j.rser. 2017.08.042.

Sjollema, S., Redondo-Hasselerharm, P., Lslie, H., Kraak, M., Vethaak, A., 2016. Do plastic particles affect microalgal photosynthesis and growth? Aquat. Toxicol. 170, 259-261. doi:10.1016/j.aquatox.2015.12.002.

Slootmaekers, B., Carteny, C., Belpaire, C., Saverwyns, S., Fremout, W., Blust, R., Bervoets, L., 2019. Microplastic contamination in gudgeons (Gobio gobio) from Flemish rivers (Belgium). Environ. Pollut. 244, 675-684. doi:10.1016/j.envpol. 2018.09.136.

Storck, F., Kools, S., Rinck-Pfeiffer, S., 2015. Microplastics in freshwater resources. Sci. Brief Glob. Water Res. Coalit.. http://www.globalwaterresearchcoalition.net/ _r2618/media/system/attrib/file/705/GWRC\%20Science\%20Brief\%20Microplastics \%20\%28September\%202015\%29.pdf.

Subramoniam, A., Asha, V., Nair, S., Sasidharan, S., Sureshkumar, P., Rajendran, K., Karunagaran, D., Ramalingam, K., 2012. Chlorophyll Revisited: Antiinflammatory Activities of Chlorophyll a and Inhibition of Expression of TNF$\alpha$ Gene by the Same. Inflammation 35, 959-966. doi:10.1007/s10753-0119399-0.

Sun, J., Dai, X., Wang, Q., Loosdrecht, M., Ni, B., 2019. Microplastics in wastewater treatment plants: detection, occurance and remover. Water Res. 152, 21e37. doi:10.1016/j.watres.2018.12.050.

Talvitie, J., Mikola, A., Setala, O., Heinonen, M., Koistinen, A., 2017b. How well is microlitter purifted from wastewater?- A detailed study on the stepwise remova! of microlitter in a tertiary levei wastewater treatment plant. Water Res. 109, 164-172.
UN environment, 2018. World Environment Day 2018: Overview. Sci. Total Environ. OpenSci. 1, 140317. doi:10.1098/rsos.140317.

Van Cauwenberghe, L., Vanreusel, A., Mees, J., Janssen, C.R., 2013. Microplastic pollution in deep-sea sediments. Environ. Pollut. 182, 495-499. doi:10.1016/j.envpol. 2013.08.013.

Vandamme, D., Gheysen, L., Muylaert, K., Foubert, I., 2018. Impact of harvesting method on total lipid content and extraction efficiency for Phaeodactylum tricornutum. Sep. Purif. Technol. 194, 362-367. doi:10.1016/j.seppur.2017.10.035.

Venghaus, D., Barjenbruch, M., 2017. Microplastics in urban water management. Environ. Eng. 1, 137-146. doi:10.4467/2353737XCT.17.011.6108.

Verschoor, A., Poorter, L., Roex, E., Bellert, B., 2014. Quick scan and prioritization of microplastic sources and emissions. RIVM Advis. Lett. 250012001.

Wang, W., Gao, H., Jin, S., Li, R., Na, G., 2019b. The ecotoxicological effects of microplastics on aquatic food web, from primary producer to human: A review. Ecotox. Environ. Safe. 173, 110-117. doi:10.1016/j.ecoenv.2019.01.113.

Wang, X., Balamurugan, S., Zhang, M., Yang, W., Liu, J., Li, H., Lin, C., 2019a. Enhanced polyunsaturated fatty acid production using food wastes and biofuels byproducts by an evolved strain of Phaeodactylum tricornutum. Bioresour. Technol. doi:10.1016/j.biortech.2019.122351.

Woodall, L., Sanchez-Vidal, A., Canals, M., Paterson, G., Coppock, R., Sleight, V., Thompson, R., 2014. The deep sea is a major sink for microplastic debris. $\mathrm{R}$ Soc. 1, 140317. doi:10.1098/rsos.140317.

Wright, S., Thompson, R., Galloway, T., 2013. The physical impacts of microplastics on marine organisms: A review. Environ. Pollut. 178, 483-492. doi:10.1016/j. envpol.2013.02.031.

Yokota, K., Waterfield, H., Hastings, C., Davidson, E., Kwietniewski, E., Wells, B., 2017. Finding the missing piece of the aquatic plastic pollution puzzle: Interaction between primary producers and microplastics. Limnol. Oceanogr. Lett. 2, 91104. doi:10.1002/lol2.10040.

Yoneda, K., Yoshida, M., Suzuki, I., Watanabe, M., 2016. Identification of a Major Lipid Droplet Protein in a Marine Diatom Phaeodactylum tricornutum. Plant Cell. Physiol. 57, 397-406. doi:10.1093/pcp/pcv204.

Zeng, W., Li, S., Chow, W., 2002. Preliminary Studies on Burning Behavior of Polymethylmethacrylate (PMMA). J. Fire Sci. 20, 297-317. doi:10.1177| 073490402762574749.

Zhang, C., Chen, X., Wang, J., Tan, L., 2017. Toxic effects of microplastic on marine microalgae Skeletonema costatum: Interactions between microplastics and algae. Environ. Pollut. 220, 1282-1288. doi:10.1016/j.envpol.2016.11.005.

Ziajahromi, S., Neale, P., Rintoul, L., Leusch, F., 2017. Wastewater treatment plants as a pathway for microplastics: Development of a new approach to sample wastewater-based MPs. Water Res. 112, 93-99. doi:10.1016/j.watres.2017.01.042. 